\title{
Validation of SSR Markers for Imparting Disease Resistance in Tomato (Solanum lycopersicum L.)
}

\author{
T.L. Dheemanth ${ }^{1 *}$, P.A. Nazeem ${ }^{1}$, P.G. Sadhan Kumar ${ }^{2}$, Sally K. Mathew ${ }^{3}$ and \\ M. Amaranatha Reddy ${ }^{4}$
}

\author{
${ }^{1}$ Centre for Plant Biotechnology and Molecular Biology, College of Horticulture, Kerala \\ Agricultural University, Vellanikkara, Thrissur- 680 656, Kerala, India \\ ${ }^{2}$ Department of Olericulture, ${ }^{3}$ Department of Plant Pathology, ${ }^{4}$ Department of Plant breeding, \\ College of Horticulture, Kerala Agricultural University, \\ Vellanikkara, Thrissur- 680 656, Kerala, India
}

*Corresponding author

\section{A B S T R A C T}

\section{Keywords}

Simple Sequence repeats(SSR's), Bacterial wilt, Tomato leaf curl virus (ToLCV)

\section{Article Info}

\section{Accepted:}

12 December 2017 Available Online: 10 January 2018
The simple sequence repeat (SSR) or microsatellite marker is currently the most preferred molecular marker because of its reproducibility and codominant nature. The aim of this study was to validate SSR markers for bacterial wilt (BW) and tomato leaf curl virus disease (ToLCV) in tomato. DNA isolated from the parents Mukthi and IIHR-2195 was used to validate five SSR primers already reported for BW and ToLCV. One primer SSR20 which showed good polymorphism and reproducibility among parents were selected for further validation in $\mathrm{F}_{3}$ and $\mathrm{F}_{4}$ population. SSR20 was validated on resistant $\mathrm{F}_{4}$, their corresponding $\mathrm{F}_{3}$ parental lines, along with susceptible checks. The SSR20 segregated with the trait in the $\mathrm{F}_{3}$ and $\mathrm{F}_{4}$ resistant plants and was also found expressed in few susceptible checks. SSR20 identified in the study could be utilized for marker assisted selection with respect to bacterial wilt in tomato.

\section{Introduction}

Tomato (Solanum lycopersicum L.) is one of the world's most important vegetable crop and has been the subject of genetic study for more than a century. It has offered insights into genetics, breeding and evolution. It belongs to the family Solanaceae and diversified first in Peru, Mexico where it was domesticated from its ancestor, Solanum lycopersicum cerasiforme (Cox, 2000). It then spread to all the important agroecologies of tropical, subtropical and temperate regions. The productivity of tomato in India is very less compared to world scenario. There are many constraints for less productivity and quality. The production and quality of tomato fruits are considerably affected by plant disease at different stages of crop growth and perishable nature of fruit respectively. Over two hundred diseases are listed worldwide (Gry, 1994). Among these, bacterial wilt disease is a major limiting factor in tropical, subtropical and humid regions of the world (Yabuuchi et al., 
1995). Ralstonia solanacearum, the causal agent of bacterial wilt, is one of the most devastating plant pathogenic bacteria (Mansfield et al., 2012) with a large host range encompassing more than 200 plant species which include major agricultural crops such as tomato, potato and banana (Hayward, 1991; Elphinstone, 2005).

Leaf curl caused by the Tomato Leaf Curl virus (ToLCV), a heterogenous complex of whitefly transmitted geminivirus is another serious production constraint of tomato worldwide, particularly in the Indian subcontinent. The effect of the disease is near total loss of crops. Each year ToLCV infection causes millions of dollar damage to tomato crops all over the world. Despite the efforts taken up so far, tomato leaf curl virus disease and bacterial wilt (BW) still continues to be the major limiting factors in tomato cultivation. The leaf curl virus infects the crop in all locations while bacterial wilt is more severe in warm humid tropics. Acidic soils, humid climate and high temperature favour bacterial wilt incidence in Kerala and it affects the crop at all stages of growth resulting in total crop loss. Leaf curl virus incidence is also gaining importance in the state recently and hence it is the need of the hour to develop varieties with combined resistance. Conventional breeding has helped to develop location specific varieties and molecular breeding have identified several Resistant Gene Analogues and QTLs mapped on different chromosomes. Considering the importance of bacterial wilt in Kerala, Kerala Agricultural University has developed varieties with relatively good resistance to Bacterial wilt (eg- Mukthi), but are susceptible to ToLCV and fruit qualities are not superior. Genotypes resistant to different strains of ToLCV have been developed at Indian Institute of Horticultural Research (eg- IIHR2195) and this project is an attempt to incorporate combined resistance to $\mathrm{BW}$ and
ToLCV through molecular breeding. The markers that will be validated will be of great use in marker assisted selection. An ideal genotype with ToLCV resistance in bacterial wilt resistance background and having desirable horticultural traits is targeted in the programme.

\section{Materials and Methods}

Bacterial wilt resistant variety Mukthi, released from Kerala Agricultural University and ToLCV resistant genotype IIHR-2195 identified at Indian Institute of Horticulture Research, Bangalore, were raised in pots during March-June, 2013, for screening the primers (SSR) already reported for disease resistance in tomato.

Five bacterial wilt resistant genotypes viz., Anagha, Sakthi, Mukthi, LE 1-2 and LE 626 were crossed with seven Tomato leaf curl virus (ToLCV) resistant genotypes viz., IIHR 2195, IIHR 2196, H 24, H 86, Hawaii 7998, LE 474 and LE 640 in a line $x$ tester fashion in an earlier work by the research group (Yadav, 2011). The thirty five $F_{1}$ hybrids of the cross Mukthi X IIHR 2195 along with their parents were grown in a wilt sick field to study their reaction to bacterial wilt and ToLCV during August-November, 2010 (Yadav, 2011). The $\mathrm{F}_{2}$ 's of thirty five crosses were grown in bacterial wilt sick field to screen for bacterial wilt and ToLCV resistance during FebruaryMay, 2011 (Yadav, 2011). Among the $F_{2}$ segregants, 30 segregants were found promising and resistant to both ToLCV and bacterial wilt (Yadav, 2011). $\mathrm{F}_{3}$ population was raised from the seeds obtained from five $\mathrm{F}_{2}$ plants which showed combined resistance (Dheemanth et al., 2017). $\mathrm{F}_{4}$ population was raised from the seeds obtained from $22 \mathrm{~F}_{3}$ plants which showed combined resistance and 35 plants were found tolerant to both the diseases (Dheemanth et al., 2017). In the present study, selected SSR markers validated 
in parental population were further applied on resistance and susceptible plants in $\mathrm{F}_{3}$ and $\mathrm{F}_{4}$ population.

\section{Screening and analysis of SSR primers}

DNA was extracted using CTAB procedure developed by Rogers and Bendich (1994). Five SSR primers already reported in tomato are listed in Table 1 were screened with parents (Mukthi and IIHR-2195) and those primers which gave polymorphism in parents were selected for screening $\mathrm{F}_{3}$ and $\mathrm{F}_{4}$ population by PCR for SSR analysis. The amplified products were run on two per cent agarose gel using 1X TAE buffer stained with ethidium bromide along with molecular weight marker (100bp ladder). The profile was visualized under UV (312 nm) transilluminator and documented. The documented SSR profiles were carefully examined for amplification of DNA.

\section{Results and Discussion}

Five SSR primers were screened using the DNA isolated from Mukthi and IIHR-2195 to select the primers showing good amplification and polymorphism among the parents. The number of bands obtained using the SSR primers ranged from 1 to 2 (Table 2). The amplification pattern obtained for SSR primers is shown in Plate 1. Among the five SSR primers only one (SSR 20) gave polymorphism among the parents Mukthi and IIHR-2195. The primer SSR 20 gave two distinct bands for IIHR-2195 out of which shared one with the variety Mukthi, thus the band of size $180 \mathrm{bp}$ was found polymorphic among the two parents. The other primers gave monomorphism among the parents so they were not selected for validation in $\mathrm{F}_{3}$ and $\mathrm{F}_{4}$ plants. Different sources of resistance and linkage of the markers with the QTL may be the reason for not obtaining polymorphism to characterize Mukthi and IIHR-2195 with all the reported markers in the present study.

The selected SSR marker was further tested on $\mathrm{F}_{3}$ and $\mathrm{F}_{4}$ population for confirming their segregation pattern. The bacterial wilt specific primer SSR 20 which showed polymorphism among the parents Mukthi and IIHR-2195 was evaluated on $\mathrm{F}_{4}$ progenies with combined resistance for bacterial wilt and ToLCV along with its $F_{3}$ parent and susceptible $F_{3}$ lines. These $F_{4}$ lines, their $F_{3}$ parent; when analyzed indicated monomorphism to wilt resistant parent Mukthi representing 180bp band (Table $3)$.

The bacterial wilt specific band was however also found present in some of the susceptible $\mathrm{F}_{3}$ progenies evaluated. The selected $\mathrm{F}_{4}$ plants derived from $5 \mathrm{~F}_{2}$ lines were validated against the primer SSR20 along with their corresponding $\mathrm{F}_{3}$ parents and few susceptible lines.

In all the 5 sets of resistant plants the specific band for wilt resistance $(180 \mathrm{bp})$ was amplified. However the susceptible once gave different amplification patterns. Some of them gave heterozygous banding pattern as expected (Plate 3b, 4b, 6b). Few other susceptible once gave banding pattern similar to resistant once (Plate 2a, 3b, 4b, 6b) and others did not amplify at all (Plate 2b, 3a, 4a, $5,6 a)$. This can be expected in a segregating population for a trait controlled by recessive genes and multiple alleles. Nazeem et al., (2010) reported that polymorphic band in resistant genotypes and several SNP and other PCR-based markers associated with BW resistance genes on tomato chromosomes 6 and 12. 
Table.1 List of SSR primers screened with tomato samples

\begin{tabular}{|c|c|c|c|c|}
\hline $\begin{array}{l}\text { SI } \\
\text { No }\end{array}$ & $\begin{array}{c}\text { Name } \\
\text { of } \\
\text { Primers }\end{array}$ & & Sequence & Source \\
\hline \multirow[t]{2}{*}{1} & \multirow{2}{*}{$\begin{array}{l}\text { LEaat } \\
007\end{array}$} & $\mathrm{~F}$ & 5' CAA CAG CAT AGT GGA GGA GG 3' & \multirow{6}{*}{ (He et al., 2003) } \\
\hline & & $\mathrm{R}$ & 5' TAC ATT TCT CTC TCT CCC ATG AG 3' & \\
\hline \multirow[t]{2}{*}{2} & \multirow{2}{*}{$\begin{array}{l}\text { LEat } \\
006\end{array}$} & $\mathrm{~F}$ & 5' CAT AAT CAC AAG CTT CTT TCG CCA 3' & \\
\hline & & $\mathrm{R}$ & 5' CAT ATC CGC TCG TTT CGT TAT GTA AT 3' & \\
\hline \multirow[t]{2}{*}{3} & \multirow{2}{*}{$\begin{array}{c}\text { LEaat } \\
002\end{array}$} & $\mathrm{~F}$ & 5' GCG AAG AAG ATG AGT CTA GAG CAT AG 3' & \\
\hline & & $\mathrm{R}$ & 5' СТС ТСТ ССС ATG AGT ТСТ ССТ СТT C 3' & \\
\hline \multirow[t]{2}{*}{4} & \multirow{2}{*}{$\begin{array}{c}\text { SSR } \\
20\end{array}$} & $\mathrm{~F}$ & 5' GAG GAC GAC AAC AAC AAC GA 3' & \multirow{4}{*}{$\begin{array}{l}\text { Sol Genome } \\
\text { Project }\end{array}$} \\
\hline & & $\mathrm{R}$ & 5' GAC ATG CCA CTT AGA TCC ACC A 3' & \\
\hline \multirow[t]{2}{*}{5} & \multirow{2}{*}{$\begin{array}{l}\text { SSR } \\
306\end{array}$} & $\mathrm{~F}$ & $5^{\prime}$ ACA TGA GCC CAA TGA ACC TC $3^{\prime}$ & \\
\hline & & $\mathrm{R}$ & 5' AAC CAT TCC GCA CGT ACA TA 3' & \\
\hline
\end{tabular}

Table.2 Number of bands and amplification patterns of SSR primers in parental genotypes Mukthi and IIHR-2195

\begin{tabular}{|l|c|c|c|c|c|c|}
\hline \multirow{2}{*}{ SI.No } & \multicolumn{3}{|c|}{ SSR Primers } & \multicolumn{2}{c|}{$\begin{array}{c}\text { Number of amplicons } \\
\text { observed }\end{array}$} & $\begin{array}{c}\text { Amplification } \\
\text { pattern }\end{array}$ \\
\hline & Number & \multicolumn{2}{|c|}{ Specificity } & Mukthi & IIHR-2195 & \\
\hline 1. & LEaat 007 & BW & ToLCV & 1 & 1 & Monomorphic \\
\hline 2. & LEaat 002 & BW & ToLCV & 1 & 1 & Monomorphic \\
\hline 3. & SSR 306 & Nil & Nil & 2 & 2 & Monomorphic \\
\hline 4. & LEaat 006 & BW & ToLCV & 1 & 1 & Monomorphic \\
\hline 5. & SSR 20 & BW & Nil & 1 & 2 & Polymorphic \\
\hline
\end{tabular}

Table.3 Segregation pattern of SSR20 marker in $\mathrm{F}_{3}$ and $\mathrm{F}_{4}$ population

\begin{tabular}{|c|c|c|c|c|c|c|}
\hline \multirow[t]{2}{*}{ S. No. } & \multirow{2}{*}{$\begin{array}{c}\text { Marker } \\
\text { type }\end{array}$} & \multirow[t]{2}{*}{ Name } & \multirow[t]{2}{*}{$\mathrm{F}_{4}$ line } & \multirow{2}{*}{$\begin{array}{l}\text { Number of } \\
\text { plants with } \\
\text { combined } \\
\text { resistance }\end{array}$} & \multicolumn{2}{|c|}{ Marker segregations } \\
\hline & & & & & $\mathbf{F}_{4}$ & $F_{3}$ parent \\
\hline 1. & SSR & SSR20 & $54-31$ & 4 & $4 / 4$ & $1 / 1$ \\
\hline 2. & & & $38-50$ & 5 & $5 / 5$ & $1 / 1$ \\
\hline 3. & & & $54-67$ & 4 & $4 / 4$ & $1 / 1$ \\
\hline 4. & & & $38-49$ & 3 & $3 / 3$ & $1 / 1$ \\
\hline 5. & & & $54-57$ & 3 & $3 / 3$ & $1 / 1$ \\
\hline
\end{tabular}


Plate.1 Screening of SSR primers with the parents Mukthi and IIHR-2195

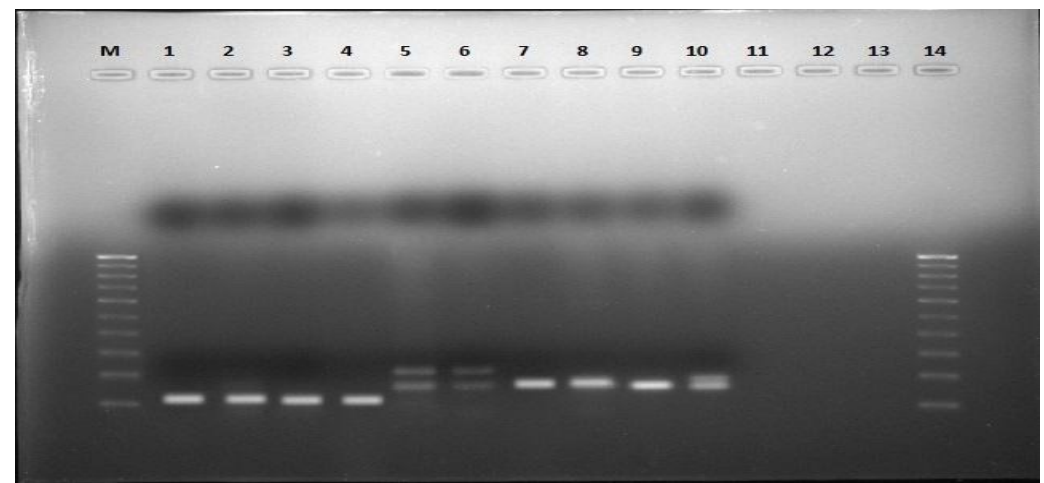

M and 14- Marker (100bp), 1- LEaat 007 with Mukthi, 2- LEaat 007 with IIHR-2195, 3- LEaat 002 with Mukthi, 4LEaat 002 with IIHR-2195, 5- SSR 306 with Mukthi, 6- SSR 306 with IIHR-2195, 7 - LEaat 006 with Mukthi, 8LEaat 006 with IIHR-2195, 9- SSR 20 with Mukthi, 10- SSR 20 with IIHR-2195.

Plate.2a Validation of BW specific marker SSR 20 on $\mathrm{F}_{4}$ segregants with combined resistance along with the $\mathrm{F}_{3}$ parent and $\mathrm{F}_{3}$ susceptible ones

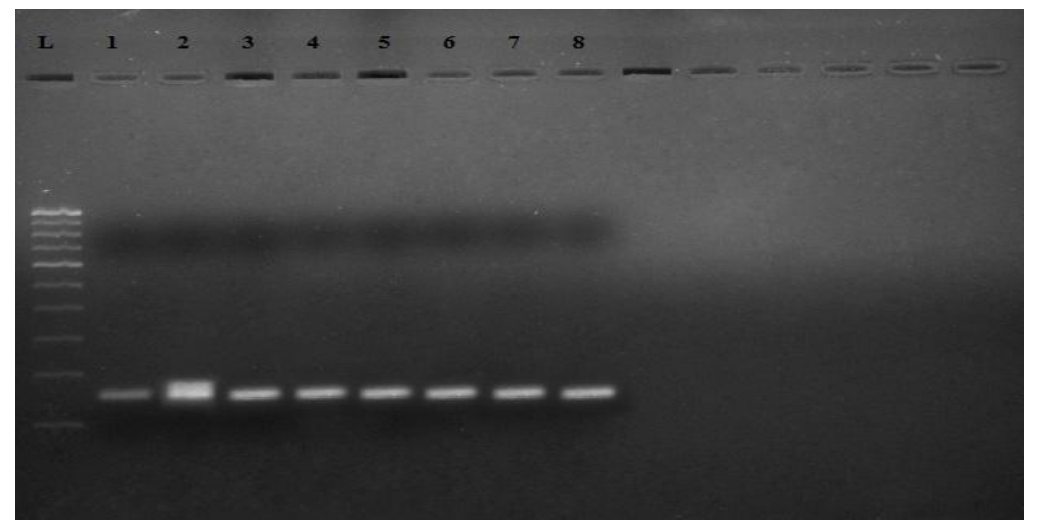

L- Ladder (100bp), 1- Mukthi, 2- IIHR-2195, 3- $\mathrm{F}_{3}$ Parent ( $\left.\mathrm{F}_{2}-54-31\right)$, 4- $\mathrm{F}_{4}$ resistant $\left(\mathrm{F}_{3}-54-31-19\right)$, 5- $\mathrm{F}_{4}$ resistant $\left(\mathrm{F}_{3}-54-31-25\right), 6-\mathrm{F}_{4}$ resistant $\left(\mathrm{F}_{3}-54-31-33\right)$, 7- Susceptible $\left(\mathrm{F}_{2}-47-6\right), 8$ - Susceptible $\left(\mathrm{F}_{2}-47-14\right)$.

Plate.2b Validation of BW specific marker SSR 20 on $\mathrm{F}_{4}$ segregants with combined resistance along with the $\mathrm{F}_{3}$ parent and $\mathrm{F}_{3}$ susceptible ones

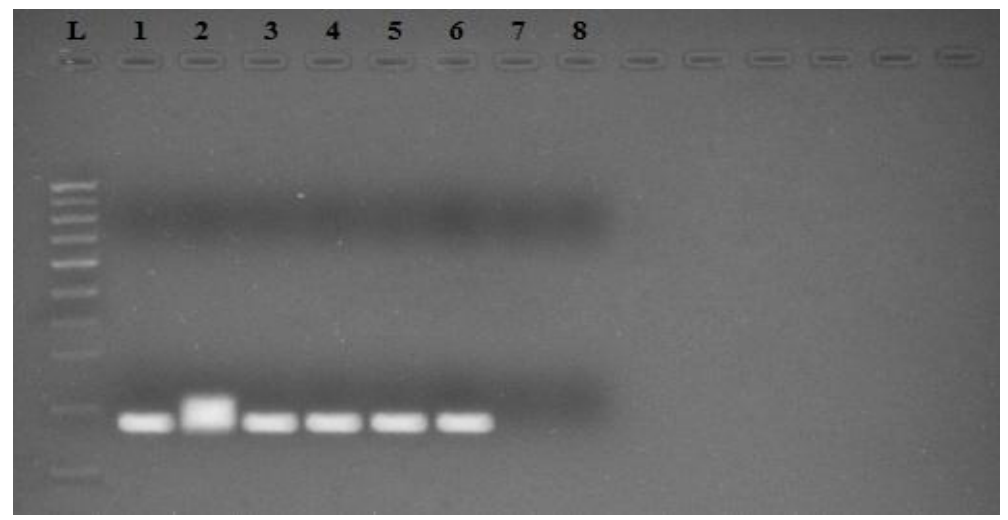

L- Ladder (100bp), 1- Mukthi, 2- IIHR-2195, 3- $\mathrm{F}_{3}$ Parent $\left(\mathrm{F}_{2}-54-31\right)$, 4- $\mathrm{F}_{4}$ resistant $\left(\mathrm{F}_{3}-54-31-19\right)$, 5- $\mathrm{F}_{4}$ resistant $\left(\mathrm{F}_{3}-54-31-25\right), 6-\mathrm{F}_{4}$ resistant $\left(\mathrm{F}_{3}-54-31-33\right)$, 7- Susceptible $\left(\mathrm{F}_{2}-38-1\right)$, 8- Susceptible $\left(\mathrm{F}_{2}-38-3\right)$. 
Plate.3a Validation of SSR 20 in $\mathrm{F}_{3}$ and $\mathrm{F}_{4}$ (38-50 line) for bacterial wilt resistance in tomato

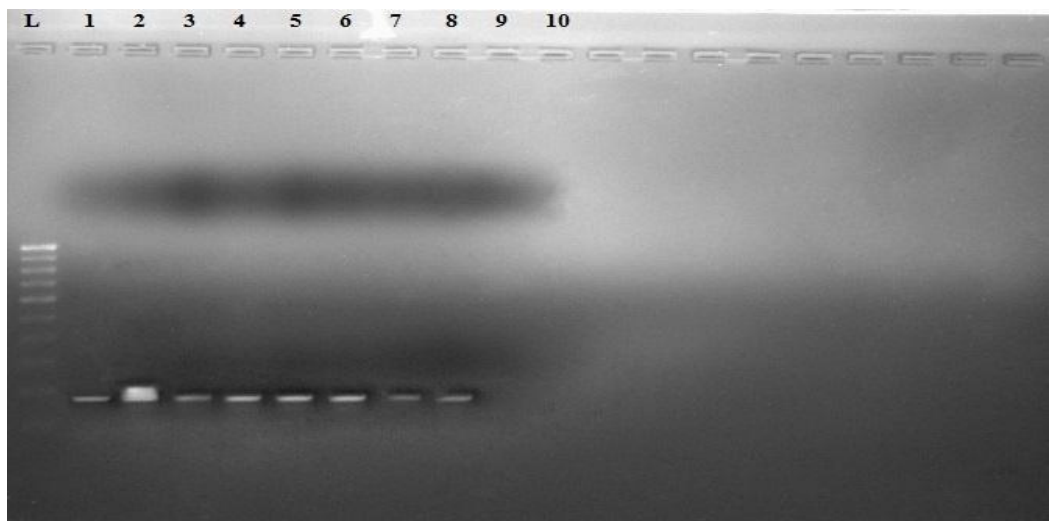

L- Ladder (100bp), 1- Mukthi, 2- IIHR-2195, 3- $\mathrm{F}_{3}$ Parent ( $\left.\mathrm{F}_{2}-38-50\right)$, 4- $\mathrm{F}_{4}$ resistant $\left(\mathrm{F}_{3}-38-50-18\right)$, 5- $\mathrm{F}_{4}$ resistant $\left(\mathrm{F}_{3}-38-50-26\right)$, 6- $\mathrm{F}_{4}$ resistant $\left(\mathrm{F}_{3}-38-50-31\right)$, 7- $\mathrm{F}_{4}$ resistant $\left(\mathrm{F}_{3}-38-50-35\right)$, 8- $\mathrm{F}_{4}$ resistant $\left(\mathrm{F}_{3}-38-50-39\right)$, 9Susceptible $\left(\mathrm{F}_{2}-38-1\right)$, 10- Susceptible $\left(\mathrm{F}_{2}-38-3\right)$.

Plate.3b Validation of SSR 20 in $\mathrm{F}_{3}$ and $\mathrm{F}_{4}$ (38-50 line) for bacterial wilt resistance in tomato

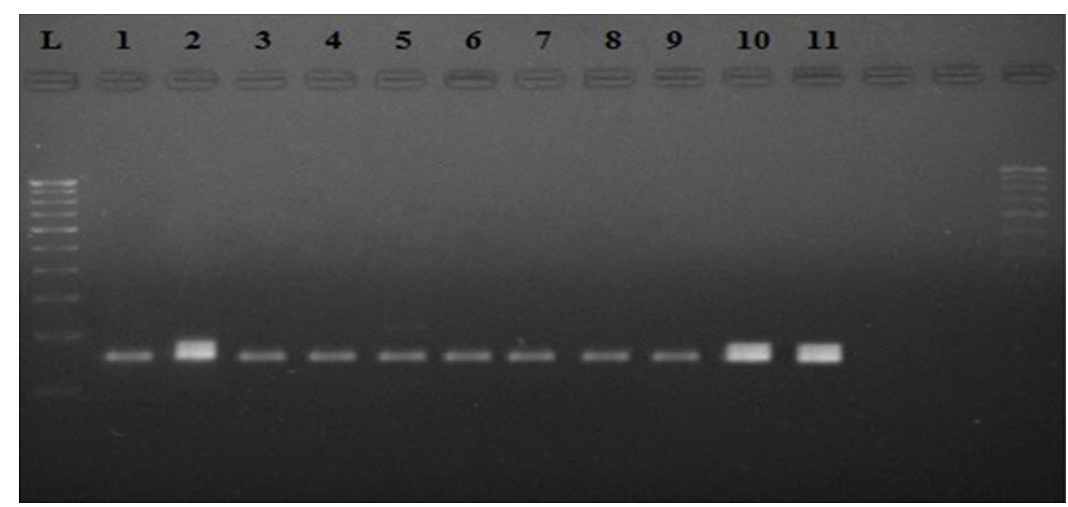

L- Ladder (100bp), 1- Mukthi, 2- IIHR-2195, 3- $\mathrm{F}_{3}$ Parent ( $\left.\mathrm{F}_{2}-38-50\right)$, 4- $\mathrm{F}_{4}$ resistant $\left(\mathrm{F}_{3}-38-50-18\right)$, 5- $\mathrm{F}_{4}$ resistant $\left(\mathrm{F}_{3}-38-50-26\right)$, 6- $\mathrm{F}_{4}$ resistant $\left(\mathrm{F}_{3}-38-50-31\right), 7-\mathrm{F}_{4}$ resistant $\left(\mathrm{F}_{3}-38-50-35\right)$, 8- $\mathrm{F}_{4}$ resistant $\left(\mathrm{F}_{3}-38-50-39\right)$, 9Susceptible $\left(\mathrm{F}_{2}-38-66\right), 10$ - Susceptible $\left(\mathrm{F}_{2}-41-5\right), 11-$ Susceptible $\left(\mathrm{F}_{2}-41-74\right)$.

Plate.4a Validation of SSR 20 in $\mathrm{F}_{3}$ and $\mathrm{F}_{4}(54-67$ line) for bacterial wilt resistance in tomato

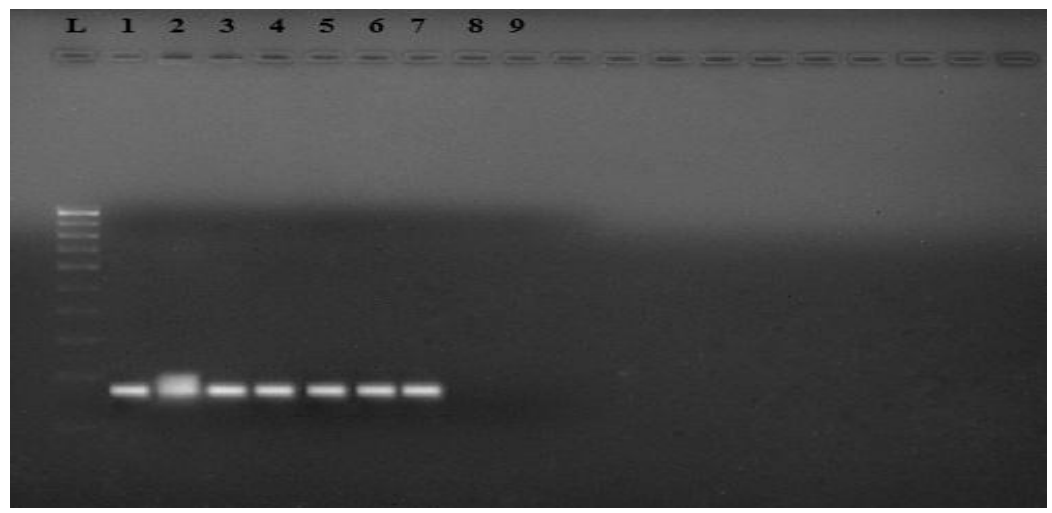

L- Ladder (100bp), 1- Mukthi, 2- IIHR-2195, 3- $\mathrm{F}_{3}$ Parent ( $\left.\mathrm{F}_{2}-54-67\right), 4-\mathrm{F}_{4}$ resistant $\left(\mathrm{F}_{3}-54-67-18\right)$, 5- $\mathrm{F}_{4}$ resistant $\left(\mathrm{F}_{3}-54-67-22\right), 6-\mathrm{F}_{4}$ resistant $\left(\mathrm{F}_{3}-54-67-23\right), 7-\mathrm{F}_{4}$ resistant $\left(\mathrm{F}_{3}-54-67-28\right), 8$ - Susceptible $\left(\mathrm{F}_{2}-38-1\right)$, 9- Susceptible ( $\left.\mathrm{F}_{2}-38-3\right)$. 
Plate.4b Validation of SSR 20 in $\mathrm{F}_{3}$ and $\mathrm{F}_{4}$ (54-67 line) for bacterial wilt resistance in tomato

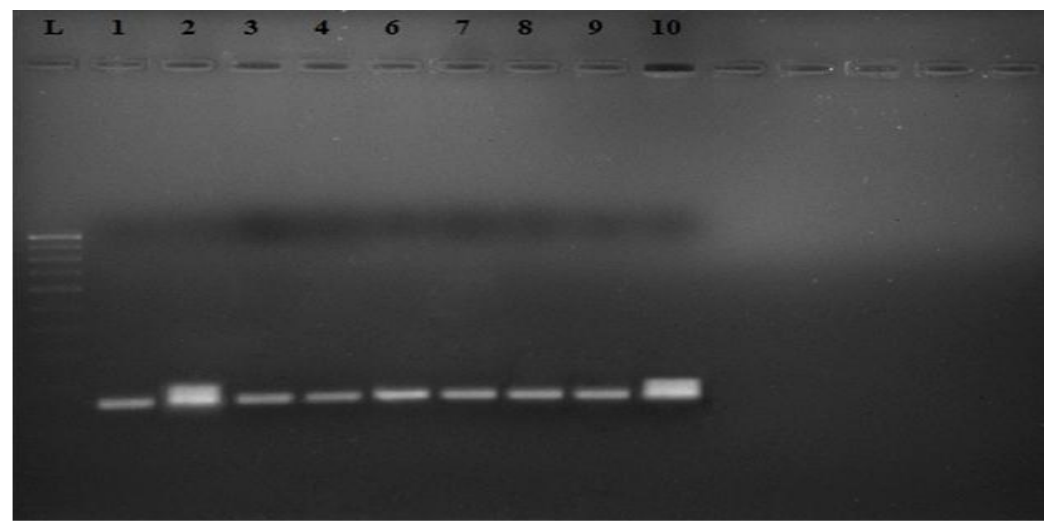

L- Ladder (100bp), 1- Mukthi, 2- IIHR-2195, 3- $\mathrm{F}_{3}$ Parent $\left(\mathrm{F}_{2}-54-67\right)$, 4- $\mathrm{F}_{4}$ resistant $\left(\mathrm{F}_{3}-54-67-18\right)$, 6- $\mathrm{F}_{4}$ resistant $\left(\mathrm{F}_{3}-54-67-22\right), 7-\mathrm{F}_{4}$ resistant $\left(\mathrm{F}_{3}-54-67-23\right), 8-\mathrm{F}_{4}$ resistant $\left(\mathrm{F}_{3}-54-67-28\right)$, 9- Susceptible $\left(\mathrm{F}_{2}-38-66\right)$, 10- Susceptible $\left(\mathrm{F}_{2}-41-5\right)$.

Plate.5 Validation of SSR 20 in $\mathrm{F}_{3}$ and $\mathrm{F}_{4}$ (38-49 line) for bacterial wilt resistance in tomato

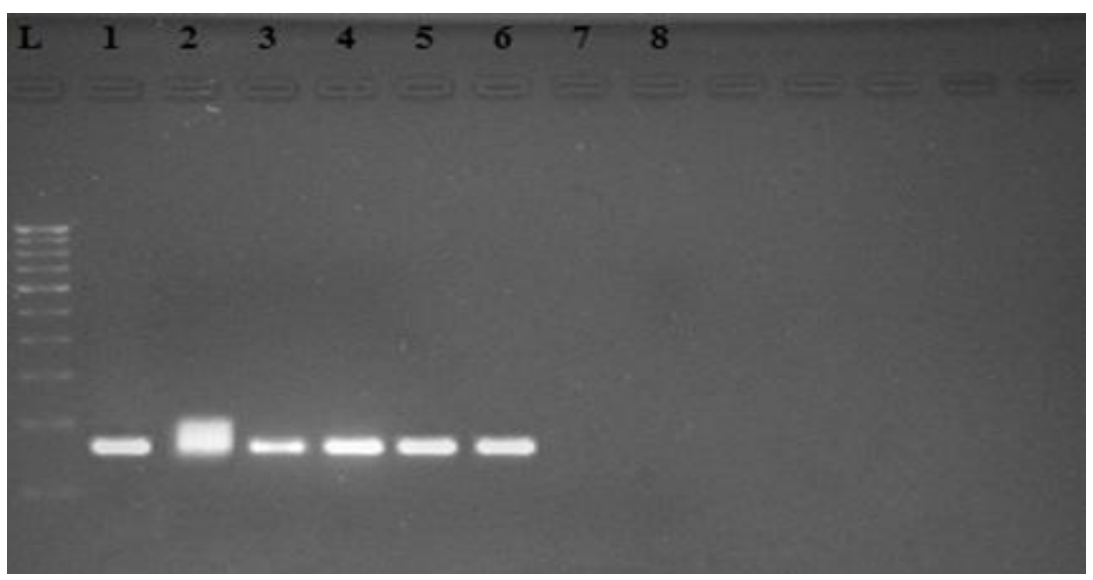

L- Ladder (100bp), 1- Mukthi, 2- IIHR-2195, 3- $\mathrm{F}_{3}$ Parent $\left(\mathrm{F}_{2}-38-49\right)$, 4- $\mathrm{F}_{4}$ resistant $\left(\mathrm{F}_{3}-38-49-2\right), 5-\mathrm{F}_{4}$ resistant $\left(\mathrm{F}_{3}\right.$ 38-49-13), 6- $\mathrm{F}_{4}$ resistant $\left(\mathrm{F}_{3}-38-49-16\right)$, 7- Susceptible $\left(\mathrm{F}_{2}-41-3\right), 8$ - Susceptible $\left(\mathrm{F}_{2}-41-4\right)$.

Plate.6a Validation of SSR 20 in $\mathrm{F}_{3}$ and $\mathrm{F}_{4}$ (54-57 line) for bacterial wilt resistance in tomato

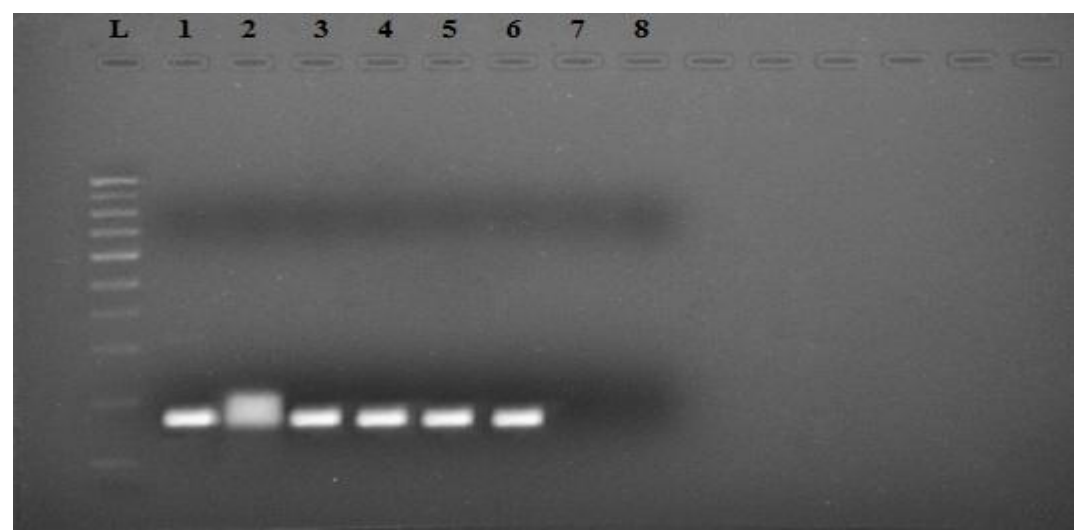

L- Ladder (100bp), 1- Mukthi, 2- IIHR-2195, 3- $\mathrm{F}_{3}$ Parent $\left(\mathrm{F}_{2}-54-57\right), 4-\mathrm{F}_{4}$ resistant $\left(\mathrm{F}_{3}-54-57-1\right), 5-\mathrm{F}_{4}$ resistant $\left(\mathrm{F}_{3^{-}}\right.$ 54-57-5), 6- $\mathrm{F}_{4}$ resistant $\left(\mathrm{F}_{3}-54-57-21\right)$, 7- Susceptible $\left(\mathrm{F}_{2}-41-3\right)$, 8- Susceptible $\left(\mathrm{F}_{2}-41-4\right)$. 
Plate.6b Validation of SSR 20 in $\mathrm{F}_{3}$ and $\mathrm{F}_{4}$ (54-57 line) for bacterial wilt resistance in tomato

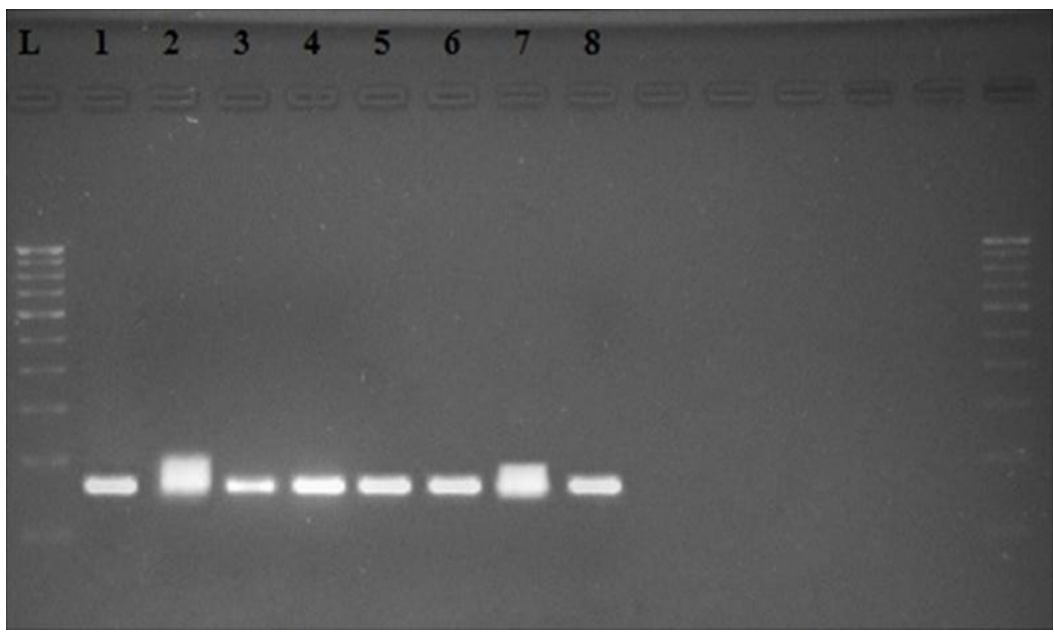

L- Ladder (100bp), 1- Mukthi, 2- IIHR-2195, 3- $\mathrm{F}_{3}$ Parent $\left(\mathrm{F}_{2}-54-57\right)$, 4- $\mathrm{F}_{4}$ resistant $\left(\mathrm{F}_{3}-54-57-1\right), 5-\mathrm{F}_{4}$ resistant $\left(\mathrm{F}_{3^{-}}\right.$ 54-57-5), 6- $\mathrm{F}_{4}$ resistant $\left(\mathrm{F}_{3}-54-57-21\right)$, 7- Susceptible $\left(\mathrm{F}_{2}-41-5\right)$, 8- Susceptible $\left(\mathrm{F}_{2}-41-4\right)$.

Different types of gene actions have been reported for bacterial wilt in tomato. Tikoo et al., (1983) have reported the presence of two independent genes for wilt resistance. The resistance was reported to be governed by multiple recessive genes in CRA 66 Sel A from Hawaii and another by single dominant gene in 663-12-3 from Taiwan. Sreelathakumari (1983) reported a complimentary and hypostatic type of digenic recessive gene system for wilt resistance in tomato. BWR-1 a pure line selection with a dominant gene for bacterial wilt resistance was developed from AVRDC accession L33 (VC 8-1-2-1) (Tikko et al., 1986). Anand et al., (1992) reported dominant gene action in the $\mathrm{F}_{1} \mathrm{~S}$ of BWR-1, BWR-5, 1661, $15 \mathrm{SB}$ and 1836 and incomplete dominance in the $F_{1} S$ of 1881 and Sonali for resistance to bacterial wilt.

In most cases resistance has been reported to be polygenic (Danesh et al., 1994; Thoquet et al., 1996; Hanson et al., 1998; Mangin et al., 1999) although in a few cases the presence of major resistance genes has been suggested. In particular, a single dominant resistance gene was reported in the genotype Hawaii 7998 (Scott et al., 1988) and Hawaii 7996
(Grimault et al., 1995). Traditional breeding for $\mathrm{BW}$ resistance has proven difficult for various reasons, including variation in pathogen populations, environmental effects on disease expression and association of resistance with undesirable horticultural characteristics such as small fruit size (Scott et al., 2005; Yang and Francis, 2007).

Thus, the use of molecular markers to assist separating $\mathrm{BW}$ resistance from undesirable horticultural characteristics, and to pyramid resistance genes from multiple sources, has been advocated (Yang and Francis, 2007). SSR20 identified in the study could be utilized for marker assisted selection with respect to bacterial wilt in tomato.

The markers found to segregate along with the trait could be recommended for marker assisted selection in tomato. To increase the utility of MAS in tomato breeding, it is imperative that additional efforts are made to identify allele specific markers and validate reported markers, which could be used across breeding populations. In some cases it may be necessary to fine map the gene(s) of interest and identify markers based on gene sequences or closely flanking sequences. 


\section{Acknowledgment}

The authors are thankful to Department of Biotechnology (DBT), Government of India for the financial support for the study.

\section{References}

Anand, N., Sadashiva, A. T., Tikoo, S. K., Ramakishun and Reddy, M. K. 1992. Resistance to bacterial wilt in tomato. Proceedings of International Conference on Bacterial wilt. Kaohsing, Taiwan, 28-31 October. pp. 152-157.

Cox, S. 2000. I Say Tomayto, You Say Tomahto. http://lamar.colostate.edu/ $\sim$ samcox /Tomato.html

Danesh, D., Aarons, S., McGill, G.E. and Young, N.D. 1994. Genetic dissection of oligogenic resistance to bacterial wilt in tomato. Mol. Plant Microbe Interact, 7: 464-471.

Dheemanth, T. L., Sadhan Kumar, P. G., Nazeem, P. A., Mathew, S, K. and Reddy, M. A. 2017. Field screening of F3 and F4 generations of tomato for combined resistance to bacterial wilt and tomato leaf curl virus (ToLCV) diseases. Vegetable Science, 44(1): 8185.

Elphinstone, J. G., The current bacterial wilt situation: a global overview. In: Allen C, Prior P, Hayward AC, editors. Bacterial Wilt Disease and the Ralstonia solanacearum Species Complex. American Phytopathological Society Press; St Paul, MN: 2005. pp. 9-28.

Grimault, V., Prior, P. and Anais, G. 1995. A monogenic dominant resistance of tomato to bacterial wilt in Hawaii-7996 is associated with plant colonization by Pseudomonas solanacearum. J. Phytopathol., 143: 349-352.

Gry, L., 1994, La tomate en révolution permanente. Semences progr, 78: 21-34.
Hanson, P.M., Licardo, O., Wang, H.J.F. and Chen, J.T. 1998. Diallel analysis of bacterial wilt resistance in tomato derived from different sources. Plant Dis., 82: 74-78.

Hayward, A. C., 1991. Biology and epidemiology of bacterial wilt caused by Pseudomonas solanacearum. Аnnu. Rev. Phytopathol., 29: 65-87.

He, C., Poysa, V., Yu, K. 2003. Development and characterization of simple sequence repeat (SSR) markers and their use in determining relationships among Lycopersicon esculentum cultivars. Theor Appl Genet. 106: 363-373.

Hedayathulla, S. and Saha, J. C. 1941. Bacterial wilt disease of tomato. Sci. Cult. 7: 226-227.

Kelman, A. 1953. The relationship of pathogenicity of Pseudomonas solanacearum. A literature review and bibliography. North Carolina Agric. Exp. Stn. Tech. Bull. 99:194.

Mangin, B., Thoquet, P., Olivier, J. and Grimsley, N.H. 1999. Temporal and multiple quantitative trait loci analyses of resistance to bacterial wilt in tomato permit the resolution of linked loci. Genetics, 151: 1165-1172.

Mansfield, J., Genin, S., Magori, S., Citovsky, V., Sriariyanum, M. and Ronald, P., 2012. Top 10 plant pathogenic bacteria in molecular plant pathology. Mol. Plant Pathol, 13: 614-629.

Nazeem, P.A., Girija, D., Sadhankumar, P.G., Nirmaladevi, S., Mathew. S.K., and Umamaheshwaran, P. 2010. Isolation and characterization of gene encoding disease resistance (ToLCV and bacterial wilt) in tomato. Final report of Soil Genome Project, Kerala Agricultural University, submitted to Department of Biotechnology, Govt. of India.

Rogers, S. O. and Bendich, A. J. 1994. Extraction of total cellular DNA from plants, algae and fungi; In: Gelvin, S. B. 
and Schilperoort, R. A. (eds.), Plant Molecular Biology manual, MA Kluwer Academic Publishers, Boston, pp. 1-8.

Rolfs, P. H. 1898. Diseases of tomato. Fla. Agr. Expt. Stn. Bull. 47:128-136.

Scott, J.W., Somodi, G.C. and Jones, J.B. 1988. Bacterial spot resistance is not associated with bacterial wilt resistance in tomato. Proc. Fla. State Hort. Soc. 101: 390-392.

Scott, J.W., Wang, J. F. and Hanson, P.M. 2005. Breeding tomatoes for resistance to bacterial wilt, a global view. Proc. 1st Intl. Symp. Tomato Dis., 695: 161-172.

Sreelathakumari, I. 1983. Incorporation of two main sources of resistance to bacterial wilt in $\mathrm{F}_{1}$ generation of tomato (Lycopersicon esculentum Mill.). M.Sc. (Ag.,) thesis, Kerala Agricultural University, Vellanikkara, Thrissur, 41p.

Thoquet, P., Olivier, J., Sperisen, C., Rogowsky, P., Prior, P., Anais, G., Mangin, B., Bazin, B., Nazer, R. and Grimsley, N. 1996. Polygenic resistance of tomato plants to bacterial wilt in the French West Indies. Mol. Plant Microbe. Interact, 9: 837-842.

Tikko, S. K., Anand, N., Kishun Ram and Reddy, P. P. 1986. Studies on breeding tomatoes for resistance to bacterial wilt (Pseudomonas solanacearum) and rootknot nematode (Meloidogyne incognita) Proc. Natl. Symp. On New Horizons in resistance breeding of vegetable crops. Feb. 14-16 February, 1986, Jabalpur, India. Abst. 14.

Tikoo, S. K., Anand, N. and Kishun, R. 1983. Presence of two independent genetic systems for resistant to bacterial wilt (Pseudomonas solanacearum). Fifteenth int. Cong. Genet., New Delhi, 12-21 December, p.1338.

Yabuuchi, E., Kosako, Y., Yano, I., Hotta, H. and Nishiuchi, Y., 1995. Transfer of Two Burkholderia and an Alcaligenes Species to Ralstonia Gen. Nov.: Proposal of Ralstonia Pickettii (Ralston, Palleroni and Doudoroff 1973) Comb. Nov., Ralstonia Solanacearum (Smith 1896) Comb. Nov. And Ralstonia Eutropha (Davis 1969) Comb. Nov. Microbiol. Immunol, 39 (11): 897-904.

Yadav, K. 2011. Incorporation of Tomato leaf curl virus (ToLCV) resistance in Bacterial wilt resistant tomato. Ph.D. thesis, Kerala Agricultural University, Vellanikkara.

Yang, W. and Francis, D.M. 2007. Genetics and breeding for resistance to bacterial diseases in tomato: prospects for marker assisted selection. In: Razdan, M.K. and Matton, A.K. (Eds.), Genetic Improvement of Solanaceous Crops Vol 2. Tomato, Science Publishers, Enfield, pp. 379-419.

\section{How to cite this article:}

Dheemanth, T.L., P.A. Nazeem, P.G. Sadhan Kumar, Sally K. Mathew and Amaranatha Reddy, M. 2018. Validation of SSR Markers for Imparting Disease Resistance in Tomato (Solanum lycopersicum L.). Int.J.Curr.Microbiol.App.Sci. 7(01): 1513-1522. doi: https://doi.org/10.20546/ijcmas.2018.701.184 